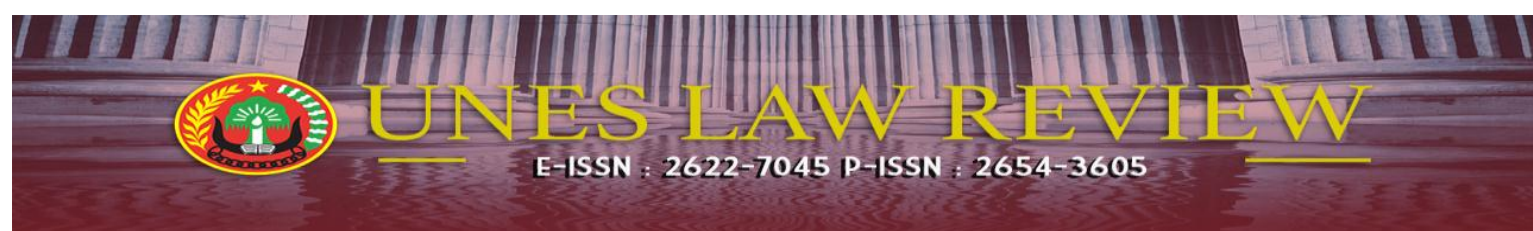

Email : uneslawreview@gmail.com Online : http://review-unes.com/index.php/law/index

Volume 1, Issue 3, Maret, 2019

E-ISSN : 2622-7045

P-ISSN : 2654-3605

\title{
EFEKTIFITAS BIMBINGAN KLIEN NARKOTIKA OLEH BALAI PEMASYARAKATAN KELAS I PADANG UNTUK MENCEGAH TINDAK PIDANA PENYALAHGUNAAN NARKOTIKA
}

\author{
${ }^{1}$ Ade Yazrul, ${ }^{2}$ Iyah Faniya \\ ${ }^{1}$ Program Magister Ilmu Hukum, Universitas Ekasakti \\ Email: adeyazru1914@yahoo.co.id \\ ${ }^{2}$ Program Magister Ilmu Hukum, Universitas Ekasakti \\ Email: iyahfaniyah@review-unes.com
}

\begin{abstract}
The implementation of narcotics client guidance by Community Guidance to prevent criminal acts of narcotics abuse is regulated in the Law of the Republic of Indonesia Number 35 of 2009 concerning Narcotics and Law of the Republic of Indonesia Number 12 of 1995 concerning Correctional Clients Guidance in practice is still a lot of dependence on narcotics. Based on the results of the study, it can be concluded that: First, the role of Bapas Class I Padang Community Supervisor in guiding clients of narcotics abuse has been carried out well, because the guidance provided by Bapas Class I Padang Community Supervisor is in the form of Post-Rehabilitation Program which is a follow-up stage given to narcotics addicts after undergoing rehabilitation which aims to guide the narcotics client to develop attitudes to society and not repeat it again. Secondly, the effectiveness of narcotics clients in preventing narcotics criminal acts at Padang Class I Correctional Facilities in principle can be said to be quite effective because every client who follows the Post-Rehabilitation Program does not have a client who repeats narcotics abuse. Third, Constraints faced in Narcotics Client Guidance at Padang Class I Correctional Institution are limited conditions and functions and lack of Human Resources (HR), as well as clients who have undergone rehabilitation to undergo post-rehabilitation services, many who have not been serious about recovering, because of the lack of family and community support in realizing the recovery of former addicts, and the lack of a place to channel their interests and potential to return to the social environment of the community. In addition, the demands of the client's economic needs become an element of strengthening the absence of clients because they cannot leave their jobs which are mostly from the private sector. Besides that, budget problems are an important factor in post-rehabilitation implementation in order to run optimally.
\end{abstract}

Kata Kunci: Efektifitas Bimbingan Klien Narkotika, Balai Pemasyarakatan, Tindak Pidana, Penyalahgunaan Narkotika 


\section{PENDAHULUAN}

Penyalahgunaan Narkotika di Indonesia merupakan masalah yang serius, dengan meningkatnya peredaran narkotika yang pada masa lalu tidak mungkin terjadi sekarang terjadi. Peristiwa - peristiwa besar penyalahgunaan narkotika sering terjadi dikalangan penegak hukum seperti kepolisian, Lembaga Pemasyarakatan dan Rumah Tahanan Negara yang seharusnya merupakan tempat resosialisasi bagi pengguna narkotika. Berita kriminal di media masa, baik media cetak maupun elektronik dipenuhi oleh berita penyalahgunaan narkotika. Korbannya meluas kesemua lapisan masyarakat dari pelajar, mahasiswa, artis, ibu rumah tangga, pedagang , supir angkot, anak jalanan, pejabat dan lain sebagainya. Narkotika dengan mudahnya dapat diracik sendiri yang sulit dideteksi. Pabrik narkotika secara ilegalpun sudah didapati di Indonesia.

Faktor-faktor yang mendorong terjadinya penyalahgunaan narkotika mengalami peningkatan yang signifikan disamping dengan kemajuan teknologi dan komunikasi bisnis narkotika merupakan bisnis yang mengiurkan artinya dengan modal dan keberanian akan mendapatkan uang yang banyak dalam waktu yang singkat, penggunaan narkotika dapat dijadikan sebagai pelarian terhadap permasalahan hidup, akibat ketidak stabilan politik, konsentrasi pemerintah lebih ditekankan kepada politik sehingga kurang terpikirnya masalah penyalahgunaan narkotika. Pemberantasan tindak pidana narkotika memerlukan biaya yang besar sehingga bagi pemerintah Indonesia belum mampu untuk menyiapkan dana tersebut.

Gambaran data di atas menunjukkan betapa sangat membahayakan peredaran dan penggunaan narkotika di negeri tercinta ini. Ancaman narkotika tidak hanya mengkuatirkan dari segi bahayanya saja melainkan dampak terhadap produktivitas bangsa ini juga perlu di perhatikan.

Generasi muda yang menjadi tulang punggung produktivitas bangsa ini harus meregang nyawa karena pemakaian narkotika. Umur produktif kerja yaitu 19-55 tahun, berhadapan dengan pengurangan jumlah penduduk produktif karena bahaya narkotika tersebut. Gejala ini sudah sewajarnya menjadi beban negara untuk menanggulanginya.

Ancaman peredaran narkotika bersifat transnasional. Ini berarti, organisasi yang canggih dengan lalu lintas antar bangsa. Pada gilirannya, narkotika menjadi viral masalah penduduk dunia. Sebagai langkah mengantisipasi situasi dan kondisi prevalensi narkotika di kalangan penduduk Indonesia, maka pemerintah mengeluarkan peraturan perundang-undangan guna mencegah dan memberantas tindak pidana narkotika yaitu Undang-Undang No. 35 Tahun 2009 tentang Narkotika.

Produk hukum yang dihasilkan pemerintah bukan hanya Undang-Undang No. 
35 Tahun 2009 tentang Narkotika saja dalam hal penanggulangan bahaya narkotika. Peraturan perundang-undangan lainnya adalah Undang-Undang No. 12 Tahun 1995 tentang Pemasyarakatan. Pendekatan integratif dalam penanganan tindak pidana narkotika ini terjamin dalam hak-hak narapidana narkotika, yaitu bagaimana klien pemasyarakatan mendapatkan bimbingan pasca rehabilitasi.

Amanat Undang-Undang No. 12 Tahun 1995 tentang Pemasyarakatan bahwa bimbingan klien pemasyarakatan adalah pembinaan klien di luar lembaga yang merupakan salah satu sistem pemasyarakatan terhadap klien. Tujuannya membentuk klien agar menjadi manusia seutuhnya, memperbaiki diri dan tidak mengulangi tindak pidana, sehingga dapat diterima kembali di lingkungan masyarakat. Mereka berperan aktif dalam pembangunan dan hidup wajar sebagai warga yang baik dan bertanggung jawab.

Undang-undang No. 12 Tahun 1995 tentang Pemasyarakatan, mengatur lebih detail tentang sistem pemasyarakatan, yaitu suatu tatanan mengenai arah dan batas serta cara pembinaan Warga Binaan Pemasyarakatan berdasarkan Pancasila yang dilaksanakan secara terpadu antara pembina, yang dibina dan masyarakat untuk meningkatkan kualitas Warga Binaan Pemasyarakatan agar menyadari kesalahan, memperbaiki diri dan tidak mengulangi tindak pidana sehingga dapat diterima kembali oleh lingkungan masyarakat dapat aktif berperan dalam pembangunan dan dapat hidup secara wajar sebagai warga yang baik dan bertanggung jawab. ${ }^{1}$ Hal ini menegaskan bahwa pembimbingan narapidana, terutama narapidana narkotika, menjadi kewajiban negara yang diwakili oleh pranata kelembagaannya yaitu Balai Pemasyarakatan (BAPAS).

Jumlah klien narkotika yang ditangani oleh Balai Pemasyarakatan Kelas I Padang pada akhir tahun 2016160 orang, sedangkan pada tahun 2017 jumlah klien meningkat menjadi 260 Orang. Dari kenyataan data yang lain ada peluang narapidana narkotika mengulang tindak pidana narkotika.

Berdasarkan latar belakang pemikiran di atas, maka permasalahan yang akan diteliti dapat dirumuskan sebagai berikut:

1. Bagaimanakah peran Balai Pemasyarakatan Kelas I Padang sebagai pembimbing klien narkotika?

2. Bagaimanakah efektivitas klien narkotika oleh Balai Pemasyarakatan untuk mencegah tindak pidana penyalahgunaan narkotika?

3. Kendala-Kendala apa saja yang dihadapi Balai Pemasyarakatan Kelas I Padang sebagai Pembimbingan Klien Narkotika?

${ }^{1}$ Direktorat Jenderal Pemasyarakatan, Standar Bimbingan Klien Dewasa, Kementerian Hukum dan HAM, Jakarta, 2016,hlm. 6 


\section{METODE PENELITIAN}

Penelitian ini merupakan penelitian hukum dengan spesifikasi deskriptif analitis. Pendekatan yang digunakan adalah pendekatan yuridis analitis yang didukung oleh pendekatan yuridis empiris. Data yang digunakan adalah data primer dan data sekunder yang diperoleh melalui studi lapangan dan studi kepustakaan yang kemudian di analisis secara kualitatif dan disajikan dalam bentuk deskriptif kualitatif.

\section{HASIL DAN PEMBAHASAN}

Peran Pembimbing Kemasyarakatan (PK) Balai Pemasyarakatan Kelas I Padang Terhadap Klien Narkoba

Penggunaan Narkotika menjadi salah satu permasalahan yang sedang marak diperbincangkan, karena tidak hanya di kalangan dewasa saja, namun narkotika sekarang juga telah menjalar kebanyak remaja atau pemuda-pemudi, sehingga dari para penggunaan narkotika ini pelaksanaan pasca rehabilitasi menjadi salah satu solusi dalam mengatasi masalah ini. Adapun lembagalembaga yang berwenang dalam membantu pelaksanaan pasca rehabilitasi salah satunya adalah "Balai Pemasyarakatan Kelas I Padang".

Pasca Rehabilitasi atau lebih dikenal aftercare adalah suatu program atau proses pemberdayaan dan pengembangan layanan rehabilitasi dengan berbagai jenis intervensi, pasca rehabilitasi merupakan tahapan pembinaan lanjutan yang diberikan kepada pecandu narkoba setelah menjalani rehabilitasi dan merupakan bagian yang integral dalam rangkaian rehabilitasi ketergantungan narkotika. Pelaksanaan pasca rehabilitasi di Balai Pemasyarakatan Klas I Padang adalah suatu tindakan yang bertujuan untuk bimbingan klien narkoba mengembangkan sikap ke masyarakatan dan tidak mengulanginya kembali. Program pasca rehabilitasi di sini di padukan dengan metode yang relevan, adanya modifikasi komunikasi secara individu atau kelompok yang bersifat kekeluargaan. Petugas Bapas berperan aktif untuk mengadakan pendekatan supaya mereka membuka diri untuk mencetuskan permasalahan yang mereka hadapi. Untuk pasca rehabilitasi di Bapas Padang terdapat empat bentuk program yaitu Pendampingan, group teraphy, Family Support Group dan Vokasional.

1. Pendampingan

Merupakan suatu strategi yang sangat menetukan keberhasilan kegiatan layanan Pasca Rehabilitasi baik perseorangan, ataupun kelompok, pada dasarnya petugas dan klien harus melakukan kerjasama untuk menghadapi tantangan dalam mencapai Pemulihan. Dalam pendampingan harus dilakukan pendekatan kepada klien supaya mereka membuka diri untuk mengemukakan permasalahan yang mereka hadapi.

2. Group teraphy

Dalam pelaksanaan kegiatan atau seminar Group teraphy, program yang diberikan seperti seminar pengembangan diri, konsultasi dokter dan konsultasi psikologi. 
Seminar pengembangan diri merupakan sarana pembinaan bagi klien narkoba yang bertujuan agar klien narkoba dapat mengetahui, memahami dan menghayati hak dan kewajiban sehingga menjadi manusia yang taat dan patuh kepada hukum, mandiri dan berguna bagi keluarga, masyarakat dan Negara. Untuk layanan pasca rehabilitasi medis, Bapas Padang menghadirkan nara sumber dari pihak rumah sakit untuk memberikan sosialisasi dampak dan bahaya narkoba bagi penggunanya dan konsultasi dokter gratis serta konsultasi psikologi dengan menghadirkan Psikolog khusus dibidang adiksi.

3. Family support group.

Pada tahapan kegiatan ini petugas Balai Pemasyarakatan Klas 1 Padang menghadirkan langsung keluarga dari klien pecandu narkoba untuk mengetahui pokok permasalahan dan penyebab klien menggunakan narkoba dan keluarga yang dihadirkan tersebut juga diharapkan dapat memberikan dukungan dan support kepada klien agar tidak lagi menggunakan narkoba.

4. Vokasional.

Program ini bertujuan untuk meningkatkan kualitas kehidupan dengan menyalurkan potensi minat dan bakat klien. Pada dasarnya Petugas Pascarehabilitasi melakukan kerjasama degan Intansi Pemerintah dan Swasta, diantaranya menghadirkan narasumber dari Kementerian Sosial dan Balai Latihan Kerja (BLK).

Kegiatan ini dilakukan untuk pembinaan kemandirian klien pemasyarakatan. Tujuan keterampilan ini adalah mempersiapkan pembekalan terhadap diri klien narkoba mengenai keahlian sehingga setelah nantinya dari pasca rehabilitasi Bapas klien narkoba sudah mempunyai keahlian untuk bekal hidup dikemudian hari. Kegiatan kemandirian ada dua bidang yaitu kegiatan kemandirian untuk hasil kegiatan kerja untuk produksi dan sebagai pelatihan bagi klien pemasyarakatan.

Efektivitas Klien Narkoba untuk Mencegah Tindak Pidana Narkotika bagi Klien Narkoba di Balai Pemasyarakatan Kelas I Padang

$$
\text { Pasca Rehabilitasi merupakan }
$$

pembinaan lanjutan yang diberikan kepada penyalah guna, korban penyalahgunaan dan/atau pecandu narkoba setelah menjalani rehabilitasi dan merupakan bagian yang integral dalam rangkaian rehabilitasi ketergantungan narkoba. Tahapn dalam pasca rehabilitasi meliputi: (a) asesmen praprogram; (b) layanan pasca rehabilitasi; serta (c) monitoring, evaluasi dan pelaporan.

Menurut Pasal 5 Undang-Undang No. 12 Tahun 1995 tentang Pemasyarakatan, salah satu sistem pembinaan pemasyarakatan adalah pembimbingan. Selanjutnya, menurut Pasal 4 huruf d Undang-Undang No 35 Tahun 2009 tentang Narkotika menerangkan bahwa tujuan dari Undang-Undang narkotika adalah untuk menjamin pengaturan upaya rehabilitasi medis dan sosial bagi penyalahguna dan pecandu narkotika. Pada Pasal 1 Peraturan Pemerintah Republik Indonesia No 31 Tahun 1999 tentang Pembinaan dan Pembimbingan Warga Binaan Pemasyarakatan menjelaskan bahwa yang dimaksud pembimbingan adalah pemberian tuntutan untuk meningkatkan kualitas, ketaqwaan terhadap Tuhan YME, 
intelektual, sikap dan perilaku profesional, kesehatan jasmani dan rohani Klien Pemasyarakatan.

Layanan Pasca Rehabilitasi yang dilakukan Balai Pemasyarakatan (BAPAS) memiliki pemberian layanan kepada para penyalahguna dan/atau pecandu narkoba diawali oleh tahapan medis dan sosial. Kemudian, dilanjutkan dengan tahapan pasca rehabilitasi, meliputi pelatihan diri dan pelatihan untuk kembali bersosialisasi dengan masyarakat dan lingkungan sekitar. Output pelatihan ini diharapkan para penyalahguna dan/atau pecandu narkoba mampu menjalani proses reintegrasi ke masyarakat, memiliki pola hidup sehat, mandiri, produktif dan berfungsi sosial.

Pelaksanaan bimbingan pasca rehabilitasi di Bapas, meliputi input data portofolio klien dari Lapas, reassesment, bimbingan pasca rehabilitasi dan integrasi klien ke masyarakat. Penegakan diagnosis sebagai basis penentuan program yang dibutuhkan oleh klien yang sesuai dengan kemajuan rehabilitasi sebelumnya. Pembimbing pemasyarakatan bertanggung jawab menghimpun, mengorganisir dan melaksanakan intervensi kegiatan bimbingan kemasyarakatan melalui tiga tahap, yaitu bimbingan awal, lanjut dan akhir. Setiap tahapan bimbingan berbekal penelitian masyarakat (litmas) yang mengukur tingkat pencapaian kemajuan klien, baik kemampuan psikis, sosial maupun teknis kemandirian produktifitasnya. Informasi kemajuan klien, menjadi bekal keputusan apakah klien dapat hidup produktif di masyarakat.

Pelaksanaan bimbingan pasca rehabilitasi meliputi registrasi klien, assesment dan tes urine. Penyampaian materi berupa penguatan identitas diri klien dengan tema "siapa diri saya". Metode yang digunakan ceramah dan tanya jawab. Pemberian materi berlangsung beberapa tahap sesuai dengan peserta yang sudah direncanakan.

Efektivitas klien narkotika dalam mencegah tindak pidana narkotika di Balai Pemasyarakatan Kelas I Padang pada prinsipnya sudah bisa dikatan cukup efektif karena setiap klien yang mengikuti Program Pasca Rehabilitasi tidak ada klien yang melakukan pengulangan tindak pidana penyalahgunaan narkotika.

Pelaksanaan bimbingan pasca rehabilitasi di Bapas, meliputi input data portofolio klien dari Lapas, reassesment, bimbingan pasca rehabilitasi dan integrasi klien ke masyarakat. Penegakan diagnosis sebagai basis penentuan program yang dibutuhkan oleh klien yang sesuai dengan kemajuan rehabilitasi sebelumnya. Pembimbing pemasyarakatan bertanggung jawab menghimpun, mengorganisir dan melaksanakan intervensi kegiatan bimbingan kemasyarakatan melalui tiga tahap, yaitu bimbingan awal, lanjut dan akhir. Setiap tahapan bimbingan berbekal penelitian 
masyarakat (litmas) yang mengukur tingkat pencapaian kemajuan klien, baik kemampuan psikis, sosial maupun teknis kemandirian produktifitasnya. Informasi kemajuan klien, menjadi bekal keputusan apakah klien dapat hidup produktif di masyarakat.

Pelaksanaan bimbingan pasca rehabilitasi meliputi registrasi klien, assesment dan tes urine. Penyampaian materi berupa penguatan identitas diri klien dengan tema "siapa diri saya". Metode yang digunakan ceramah dan tanya jawab. Pemberian materi berlangsung beberapa tahap sesuai dengan peserta yang sudah direncanakan.

\section{Kendala Dalam Pelaksanaan Pasca Rehabilitasi Di Balai Pemasyarakatan Kelas I Padang}

\section{Balai Pemasyarakatan Kelas I Padang} yang bekerjasama dengan BNN untuk menangani masalah pembimbingan khususnya upaya penanggulangan ketergantungan narkotika/ penyalahguna narkotika. Sebab dengan adanya program pembimbingan berupa pasca rehabilitasi di Bapas Padang dapat meminimalisir peredaran gelap dan penyalahgunaan narkotika di Indonesia.

Untuk menciptakan suatu program pasca rehabilitasi yang konfrehensif idealnya, menerapkan pasca rehabilitasi sebagai bagian dari sistem pembimbingan terhadap klien pemasyarakatan narkotika memerlukan usaha keras dari semua pihak yang membutuhkan keahlian, ketrampilan, motivasi, sarana dan prasarana bahkan ilmu pengetahuan dari seluruh petugas Bapas Padang serta pedomanpedoman pelaksanaan program tersebut sebagai alat pendukung pelaksanaan tugas.

Berdasarkan penelitian bahwa Program Pasca Rehabilitasi terhadap klien pemasyarakatan efektif dilaksanakan di Balai Pemasyarakatan Kelas I Padang. Untuk mencapai tujuan program ini menghadapi banyak rintangan dan hambatan, agar program dapat berjalan dengan efektif dan efisien. Ada beberapa hal yang menjadi kendala program pasca rehabilitasi di Balai Pemasyarakatan Kelas I Padang, yaitu kondisi dan fungsi yang terbatas dan kurangnya SDM (Sumber Daya Manusia). Menurut Kepala Balai Pemasyarakatan Kelas I Padang Iskandarsyah, Bc.IP, SH kendala tersebut diantaranya klien yang sudah menjalani rehabilitasi untuk menjalani layanan pasca rehabilitasi banyak yang belum bersungguh- sungguh untuk pulih, kurangnya dukungan keluarga dan masyarakat dalam mewujudkan kepulihan mantan pecandu, dan kurangnya wadah tempat menyalurkan minat dan potensi diri untuk kembali ke lingkungan sosial masyarakat. $^{2}$

Disamping itu masalah anggaran dan SDM merupakan faktor penting terhadap terlaksananya pasca rehabilitasi agar dapat berjalan maksimal. Selain itu kedisiplinan terhadap klien narkoba Bapas juga merupakan

2 Wawancara, Kepala Balai Pemasyarakatan Kelas I Padang Is kandar Bc. IP, SH, 19 Maret 2018 
masalah dalam pelaksanaan pasca rehabilitasi, untuk itu perlu adanya penanganan khusus terhadap klien narkoba Bapas.

Penanganan secara khusus terhadap klien narkoba disebabkan sifat dan kebiasaan (habbit) klien narkoba, terutama yang dikategorikan pengguna mempunyai sifat berbeda dengan kriminal lain yaitu bahwa klien narkoba ini mempunyai sifat pemalas dan susah diatur, lebih banyak menghayal.

Perbedaan sifat ini dapat di lihat dari tingkat kerajinan untuk melaksanakan perintah petugas. Mereka banyak memberi alasan untuk tidak mengikuti kegiatan pasca rehabilitasi, hal ini membuat petugas harus mempunyai keahlian khusus dan kesabaran untuk bisa membaca pola pikir klien narkoba.

Kekuranganpengetahuandan skill dari petugas dapat menjadi peng-hambat terlaksananya program pasca rehabilitasi sebagai bagian dari pembimbingan di Balai Pemasyarakatan Kelas I Padang. Selain tingkat pengetahuan yang kurang, dari sisi kuantitas pegawai juga menjadi perhatian khusus di Balai Pemasyarakatan Kelas I Padang.

\section{PENUTUP}

Berdasarkan pembahasan sebagaimana yang telah dipaparkan diatas, maka penulis dapat menarik kesimpulan sebagai berikut:

Peran Pembimbing Kemasyarakatan Bapas Kelas I Padang dalam pembimbingan klien penyalahgunaan narkotika sudah terlaksana dengan baik, karena pembimbingan yang diberikan oleh Pembimbing Kemasyarakatn Bapas Kelas I Padang berupa Program Pasca Rehabilitasi yang merupakan tahapan pembinaan lanjutan yang diberikan kepada pecandu narkotika setelah menjalani rehabilitasi yang bertujuan untuk membimbing klien narkotika mengembangkan sikap ke masyarakatan dan tidak mengulanginya kembali.

Efektivitas klien narkotika dalam mencegah tindak pidana narkotika di Balai Pemasyarakatan Kelas I Padang pada prinsipnya sudah bisa dikatan cukup efektif karena setiap klien yang mengikuti Program Pasca Rehabilitasi tidak ada klien yang melakukan pengulangan tindak pidana penyalahgunaan narkotika.

Kendala yang dihadapi dalam Pembimbingan Klien Narkotika di Balai Pemasyarakatan Kelas I Padang yaitu kondisi dan fungsi yang terbatas dan kurangnya SDM (Sumber Daya Manusia), serta klien yang sudah menjalani rehabilitasi untuk menjalani layanan pasca rehabilitasi banyak yang belum bersungguh- sungguh untuk pulih, karena kurangnya dukungan keluarga dan masyarakat dalam mewujudkan kepulihan mantan pecandu, dan kurangnya wadah tempat menyalurkan minat dan potensi diri untuk kembali ke lingkungan sosial masyarakat. Selain itu tuntutan kebutuhan ekonomi klien menjadi unsur penguat ketidak hadiran klien karena tidak bisa meninggalkan pekerjaannya 
yang sebagian besar dari sektor swasta .

Disamping itu masalah anggaran merupakan faktor penting terhadap terlaksananya pasca rehabilitasi agar dapat berjalan dengan maksimal.

\section{DAFTAR PUSTAKA}

\section{Buku}

Amin, Ahmad, Buku Tentang Bahaya Narkoba, Remaja Rosda Karya,Bandung, 1991

Apandi Yusuf, Katakan Tidak Pada Narkoba, Simbiosa Rekatama Media, Jakarta, 2010

Baharudin Surjobroto, Suatu Tinjauan Tentang Sistem Pemasyarakatan, Dep.Kehakiman RI, Jakarta, 1991

Direktorat Jenderal Pemasyarakatan, Standar Bimbingan Klien Dewasa, Kementerian Hukum dan HAM, Jakarta, 2016

R.Achmad S. Soemadipraja dan Romli Atmasasmita, Sistem Pemasyarakatan di Indonesia, Bina Cipta, Bandung, 1979

Sasangka Hari, Narkotika dan Psikotropika Dalam Hukum Pidana. Mandar Maju, Jakarta, 2003

\section{Peranturan Undang-Undang}

Undang-Undang Republik Indonesia Nomor 12 tahun 1995 tentang Pembimbingan Klien Pemasyarakatan

Undang-Undang Republik Indonesia Nomor 35 Tahun 2009 tentang Narkotika 